\title{
The combined effects of cadmium and salinity on some pigments and total phenolic compounds of Myriophyllum heterophyllum Michx. and Potamogeton crispus L.
}

\author{
Aysel SIVACI ${ }^{1 *}$ and Emire ELMAS ${ }^{2}$ \\ ${ }^{1}$ Department of Biology, Faculty of Art and Science, Adıyaman University, Adıyaman, Turkey. \\ ${ }^{2}$ Department of Biology, Faculty of Art and Science, Sinop University, Sinop, Turkey.
}

Accepted 5 June, 2012

\begin{abstract}
In this study, the combined effects of different salinity and cadmium concentrations $(0,0.05 \%, \mathrm{NaCl}+4$ $\mathrm{mg} \mathrm{L}^{-1} \mathrm{Cd}, 0.05 \% \mathrm{NaCl}+64 \mathrm{mg} \mathrm{L}^{-1} \mathrm{Cd}, 5 \% \mathrm{NaCl}+4 \mathrm{mg} \mathrm{L}^{-1} \mathrm{Cd}, 5 \% \mathrm{NaCl}+64 \mathrm{mg} \mathrm{L}^{-1} \mathrm{Cd}$ ) on some pigments (chlorophyll a, chlorophyll $b$, carotenoids and anthocyanins) and total phenolic compounds were investigated in two aquatic plants (Myriophyllum heterophyllum Michx. and Potamogeton crispus L.) at 24 and $96 \mathrm{~h}$. Chlorophyll a, chlorophyll b and carotenoids decreased depending on $\mathrm{Cd}+\mathrm{NaCl}$ concentrations and the time $(24 \mathrm{~h}$ and $96 \mathrm{~h})$ in both species $(\mathrm{P}<0.05)$. The anthocyanin concentrations showed differences in combined $\mathrm{Cd}$ and $\mathrm{NaCl}$ concentrations in both species at 24 and $96 \mathrm{~h}$. In the two time periods (24 and $96 \mathrm{~h}$ ), the levels of phenolic compounds at all concentrations of $\mathrm{Cd}+\mathrm{NaCl}$ increased in both $M$. heterophyllum and $P$. crispus $(P<0.05)$.
\end{abstract}

Key words: Aquatic plants, cadmium, sodium chloride $(\mathrm{NaCl})$, phenolic compounds, photosynthetic pigments.

\section{INTRODUCTION}

The heavy metals cause environmental pollution and they are among the most toxic pollutants. In addition to their toxicity effects even at low concentrations, they can be accumulated throughout the food chain, which leads to serious ecological and health hazards (Al-Rub et al., 2006). Cadmium (Cd) is a wide spread non-essential heavy metal, which enters the aquatic environments from natural (weathering of rocks) as well as anthropogenic sources (industrial effluents, agricultural run-offs). It causes oxidative stress by generating free radicals and toxic oxygen species. These species cause lipid peroxidation, membrane damage and inactivation of several enzymes by reacting with lipids, proteins, pigments and nucleic acids (Singh et al., 2005), and also

${ }^{*}$ Corresponding author. E-mail: asivaci@adiyaman.edu.tr. Tel: (416)2231775. Fax: +90 (416)2231774. cause oxidative stress (Aravind and Prassad, 2003) as well as a decrease in the content of chlorophyll and carotenoids (Shin et al., 2002). Mobin and Khan (2007) reported that anthocyanins in leaves of Brassica juncea, increased by cadmium stress and induction of anthocyanin accumulation, might help to protect the photosynthetic apparatus by screening it from deleterious effects of stress-generated superoxide radicals without limiting photosynthesis. Among the chemical compounds in plants, secondary metabolites have great importance in plant-environment relationships because these compounds have major ecological roles in allelophatic processes, in the protection against herbivores and in response to environmental stress of plants (Pasqualini et al., 2003). Salinity could affect the growth rate and uptake metals by plants because of the toxic effects of both sodium ( $\mathrm{Na}$ ) and chlorine $(\mathrm{Cl})$ ions. $\mathrm{Cl}$ ions also reduce the concentration of free metal ions by forming a complex with heavy metals such as $\mathrm{Cd}$ and zinc $(\mathrm{Zn})$. Thus, the 
toxic effects of heavy metals decrease in plants (Frittoff et al., 2005).

Sivaci et al. (2008) showed that Cd was significantly removed by Myriophyllum heterophyllum and Potamogeton crispus and $\mathrm{Cd}$ uptake in $P$. crispus was higher than $M$. heterophyllum. These two species are different morphologically and exhibit different biosorption capacities. They are important for polluted aquatic ecosystems because of their potential role in phytoremediation. The aquatic ecosystems are more sensitive to pollutants than terrestrial ones and aquatic plants are the first link in food chain of aquatic environments (Singh et al., 2005). Determination of physiological changes in $M$. heterophyllum (two-leaf water milfoil) and $P$. crispus (curly-leaved pondweed) due to the accumulation of the combined $\mathrm{Cd}$ and $\mathrm{NaCl}$ is important to protect the polluted aquatic ecosystems and develop several strategies in such systems. Therefore, the aim of this study is to investigate the combined effects of $\mathrm{Cd}$ and salinity on total chlorophyll a, chlorophyll b, carotenoids, anthocyanins and phenolic compounds in $M$. heterophyllum and $P$. crispus.

\section{MATERIALS AND METHODS}

The samples of $M$. heterophyllum and $P$. crispus were collected from Sinop Karagöl-Aksaz lagune (Black Sea Region/Turkey) and washed with diluted $\mathrm{HCl}$ solution (3\%), followed by distilled water before use (Keskinkan et al., 2003). Analytical grade Cd sulphate $\left(\mathrm{CdSO}_{4}\right)$ was used as the metal source and test. Experiments were conducted at $25^{\circ} \mathrm{C}$ in conical flasks $(250 \mathrm{ml}$ cadmium and $\mathrm{NaCl}$ solution at varying concentrations) using an orbital shaker (200 rpm) in a constant room temperature $\left(25 \pm 2^{\circ} \mathrm{C}, 12 \mathrm{~h}\right.$ light $/ 12 \mathrm{~h}$ dark). Macrophyte samples (2 g wet weight) were added to each flask and placed on the orbital shaker. They were exposed to the combination of $\mathrm{Cd}$ and $\mathrm{NaCl}$ at $\left(0,0.05 \%\right.$ o $4 \mathrm{mg} \mathrm{L}^{-1}, 0.05 \%$ o +64 $\mathrm{mg} \mathrm{L}^{-1}, 5 \%+4 \mathrm{mg} \mathrm{L}^{-1}, 5 \%$ o $\left.64 \mathrm{mg} \mathrm{L}^{-1}\right)$. As shown by Sivaci et al. (2008), the minimum accumulation of Cd occurred in the first $24 \mathrm{~h}$ and maximum accumulation at $96 \mathrm{~h}$ in these species, and we chose this two time points to evaluate the physiological changes. After contacting periods ( 24 and $96 \mathrm{~h}$ ), plant materials were filtered to separate the biomass from the solution for the determination of pigments and phenolic compounds. The experiments were performed in triplicate.

\section{Assay for total pigments}

Pre-exposure and post-exposure pigment contents of $M$. heterophyllum and $P$. crispus were measured after 24 and $96 \mathrm{~h}$ combined treatment with $\mathrm{Cd}$ and salinity. One gram of fresh leaves samples was extracted by following the method of De Kok and Graham (1989). The absorbance of the supernatants was measured at 662,645 for chlorophylls and $470 \mathrm{~nm}$ for carotenoids. The concentrations were calculated as described by Lichtenthaler and Wellburn (1983).

For determination of anthocyanin, $1 \mathrm{~g}$ of fresh leaves samples was extracted with $12 \mathrm{ml}$ of $1 \%(\mathrm{w} / \mathrm{v}) \mathrm{HCl}$ in methanol for 2 days at 3 to $5^{\circ} \mathrm{C}$ with continuous shaking (Mancinelli et al., 1975; Reay et al., 1998). The assay was carried out in triplicate. The absorbances of samples were measured at 530 and $657 \mathrm{~nm}$ and anthocyanin concentrations were calculated according to using the equation by
Mancinelli et al. (1975).

\section{Assay for total phenolics}

Pre-exposure and post-exposure phenolic contents of $M$. heterophyllum and $P$. crispus were measured in combination of $\mathrm{Cd}$ and salinity treatment after 24 and $96 \mathrm{~h}$. Total phenolic constituents of macrophyte species were performed by employing the literature methods involving Folin-Ciocalteu reagent and gallic acid as standard (Slinkard ve Singleton, 1977; Chandler and Dods, 1983). Briefly, $50 \mathrm{mg}$ of fresh material was homogenized in $2.5 \mathrm{ml}$ ethanol and flask was kept in a water bath at $25^{\circ} \mathrm{C}$ for $24 \mathrm{~h}$ with continuous shaking. After filtration, $1 \mathrm{ml}$ of supernatant solution was taken in a volumetric flask, and then $1 \mathrm{ml}$ ethanol and $5 \mathrm{ml}$ distilled water and $1 \mathrm{ml}$ Folin-Ciocalteu reagent were added and flask was shaken thoroughly. After $3 \mathrm{~min}, 3 \mathrm{ml}$ of solution $2 \%(\mathrm{w} / \mathrm{v}) \mathrm{Na}_{2} \mathrm{CO}_{3}$ was added and the mixture was allowed to stand for $2 \mathrm{~h}$ with intermittent shaking. Absorbance was measured at $760 \mathrm{~nm}$. The same procedure was repeated for all standard gallic acid solutions (0$1000 \mu \mathrm{g} / 0.1 \mathrm{ml}$ ) and standard curve was obtained. Total phenolic compounds of the samples were calculated using the calibration curve with the gallic acid standard.

\section{Statistical analysis}

The data from three replications of all treatments were subjected to the analysis of variance using SPSS 8.0 for Windows. Differences between means at $5 \%(P<0.05)$ level were considered significant.

\section{RESULTS}

\section{Total chlorophylls, carotenoids and anthocyanins}

In $M$. heterophyllum and $P$. crispus, it was observed that the amount of chlorophyll a, chlorophyll b and carotenoids decreased by the increase of $\mathrm{Cd}+\mathrm{NaCl}$ concentrations with time ( $24 \mathrm{~h}$ and $96 \mathrm{~h}$ ) in comparison to control (Figures 1 and 2). At $24 \mathrm{~h}$, the lowest level of pigment was observed in $0.05 \%+64 \mathrm{mg} \mathrm{L}^{-1}$ in $M$. heterophyllum and $P$. crispus, (chlorophyll a, $8.32 \mathrm{mg} \mathrm{g}^{-1}$; chlorophyll b, $2.78 \mathrm{mg} \mathrm{g}^{-1}$; carotenoids, $2.52 \mathrm{mg} \mathrm{g}^{-1}$ for $M$. heterophyllum; chlorophyll a, $8.70 \mathrm{mg} \mathrm{g}^{-1}$; chlorophyll $\mathrm{b}$, $2.94 \mathrm{mg} \mathrm{g}^{-1}$; carotenoids $5.20 \mathrm{mg} \mathrm{g}^{-1}$ for $P$. crispus) $(P<0.05)$. At $96 \mathrm{~h}$, the lowest pigment contents of $M$. heterophyllum were determined in $64 \mathrm{mg} \mathrm{L}^{-1}+5 \% \mathrm{NaCl}$ (chlorophyll a, $7.09 \mathrm{mg} \mathrm{g}^{-1}$; chlorophyll b, $2.02 \mathrm{mg} \mathrm{g}^{-1}$; carotenoids; $2.10 \mathrm{mg} \mathrm{g}^{-1}$ ) (Figure 1) $(\mathrm{P}<0.05)$. At $96 \mathrm{~h}$, the change in pigment contents of $P$. crispus (chlorophyll $a$, chlorophyll $\mathrm{b}$ and carotenoids) was similar to $M$. heterophyllum (Figures 1 and 2). It was found that the decrease rate of pigment contents depending on treatment combined $\mathrm{Cd}+\mathrm{NaCl}$ at $96 \mathrm{~h}$ was more than the $24 \mathrm{~h}$ in both species (Figures 1 and 2).

Moreover, in $M$. heterophyllum and $P$. crispus, there was significant changes in anthocyanin content except for $0.05 \% \mathrm{o}+64 \mathrm{mg} \mathrm{L}^{-1}$ and $5 \% \mathrm{o}+64 \mathrm{mg} \mathrm{L}^{-1}$ of $M$. heterophyllum at $24 \mathrm{~h}$ (Figure 3$)(\mathrm{P}<0.05)$. At $24 \mathrm{~h}$, the highest anthocyanin concentrations were observed in 4 $\mathrm{mg} \mathrm{L}^{-1} \mathrm{Cd}+5 \% \mathrm{NaCl}$ in M. heterophyllum and $64 \mathrm{mg} \mathrm{L}^{-1}$ 


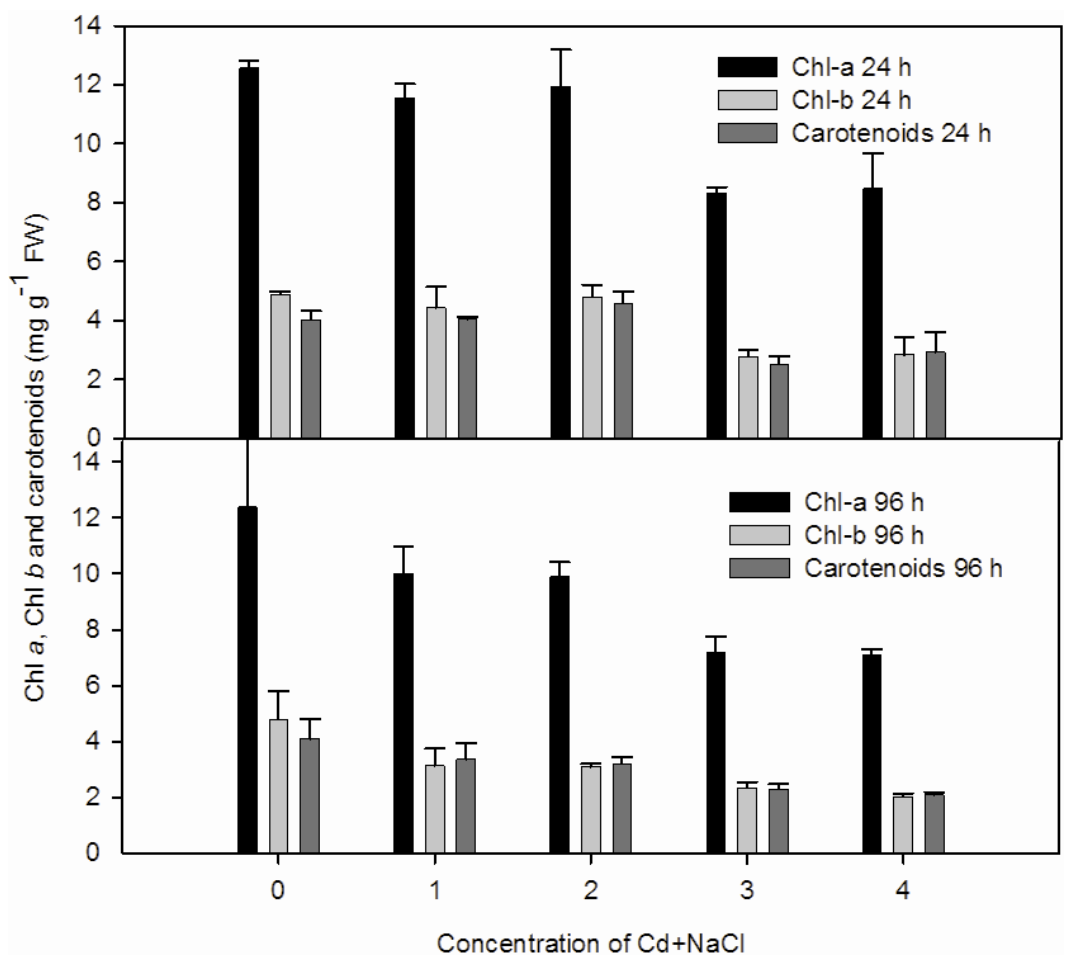

Figure 1. The combined effects of $\mathrm{Cd}$ and $\mathrm{NaCl}$ on chlorophyll a, chlorophyll $\mathrm{b}$ and carotenoids in $M$. heterophyllum at 24 and $96 \mathrm{~h}$ (0, control; $1,4 \mathrm{mg} \mathrm{L}^{-1} \mathrm{Cd}+$ $0.05 \%$ NaCl; $2,4 \mathrm{mg} \mathrm{L}^{-1} \mathrm{Cd}+5 \%$ NaCl; 3, $64 \mathrm{mg} \mathrm{L}^{-1} \mathrm{Cd}+0.05 \%$ NaCl; 4,64 $\mathrm{mg} \mathrm{L}^{-1} \mathrm{Cd}+5 \% \mathrm{NaCl}$ ) ( chlorophyll a, Chl a; chlorophyll b, Chl b).

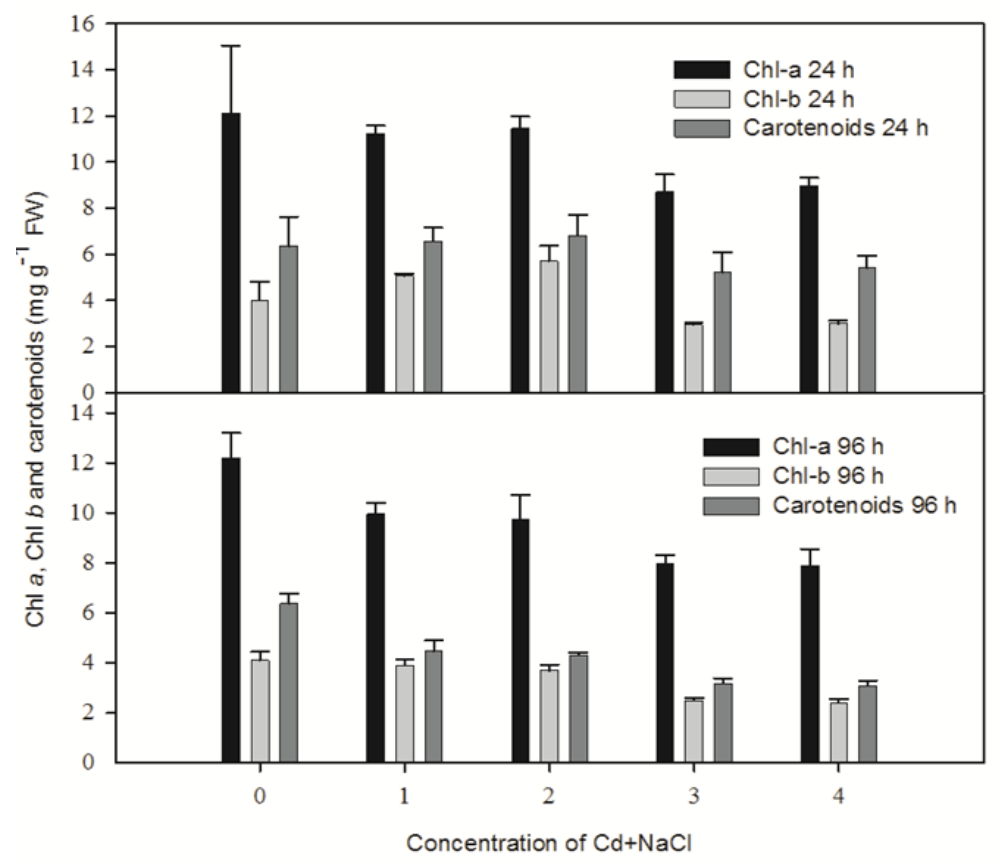

Figure 2. The combined effects of $\mathrm{Cd}$ and $\mathrm{NaCl}$ on chlorophyll a, chlorophyll b and carotenoids in P. crispus at 24 and $96 \mathrm{~h}(0$, control; 1,4 $\mathrm{mg} \mathrm{L}-1 \mathrm{Cd}+0.05 \% 0 \mathrm{NaCl} ; 2,4 \mathrm{mg} \mathrm{L}-1 \mathrm{Cd}+5 \% \mathrm{NaCl} ; 3,64 \mathrm{mg} \mathrm{L}-1 \mathrm{Cd}+$ $0.05 \%$ o NaCl; $4,64 \mathrm{mg} \mathrm{L}-1 \mathrm{Cd}+5 \%$ o NaCl) (chlorophyll a, Chl a; chlorophyll b, Chl b). 


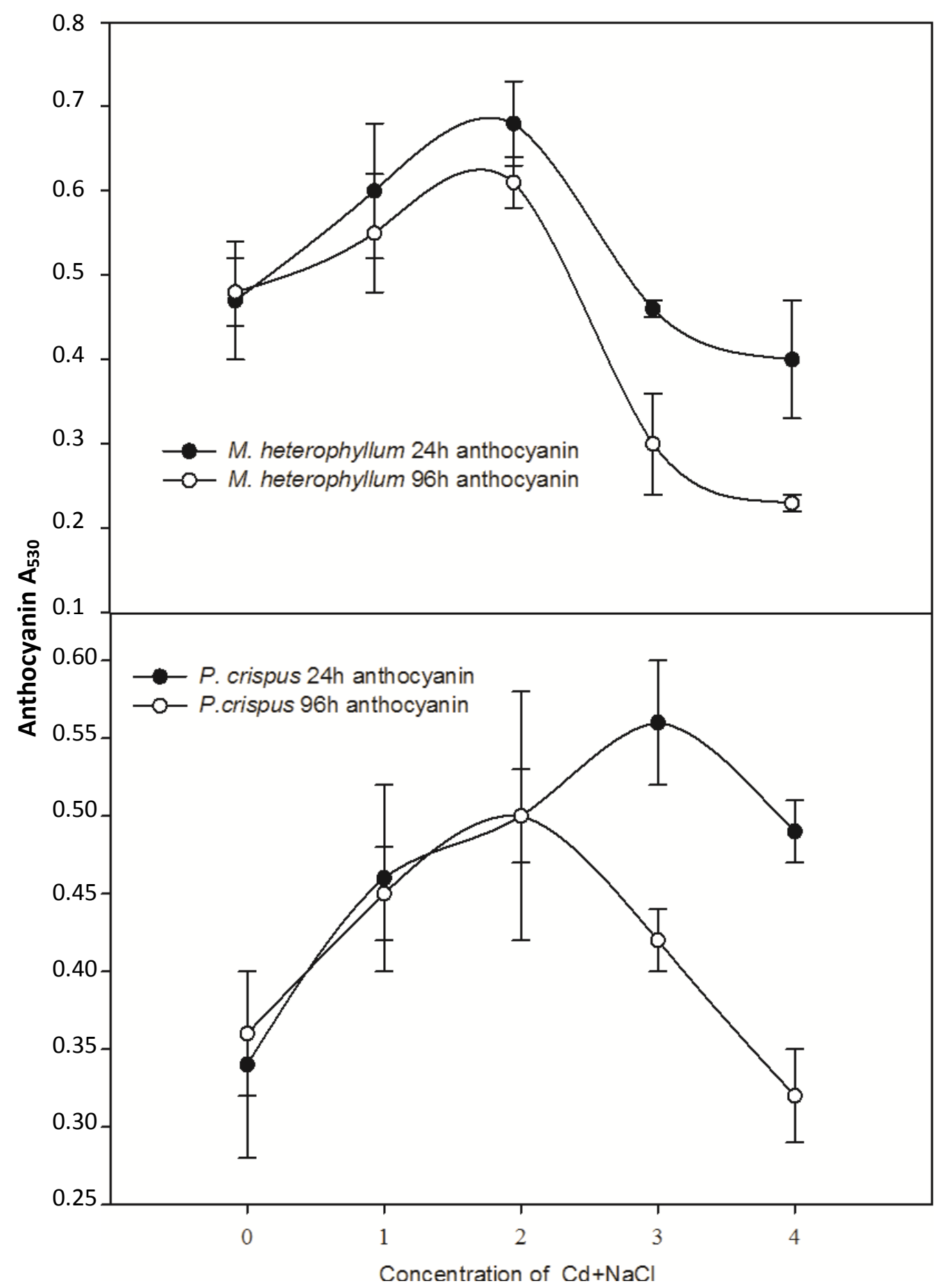

Figure 3. The combined effects of $\mathrm{Cd}$ and $\mathrm{NaCl}$ on anthocyanins in $\mathrm{M}$. heterophllum and P.crispus at 24 and $96 \mathrm{~h}$ (0, control; $1,4 \mathrm{mg} \mathrm{L}^{-1} \mathrm{Cd}+0.05 \% \mathrm{NaCl} ; 2,4 \mathrm{mg} \mathrm{L}^{-1} \mathrm{Cd}+5 \%$ NaCl; $3,64 \mathrm{mg} \mathrm{L}^{-1} \mathrm{Cd}$ $\left.+0.05 \% \mathrm{NaCl} ; 4,64 \mathrm{mg} \mathrm{L}^{-1} \mathrm{Cd}+5 \% \mathrm{NaCl}\right)$.

$\mathrm{Cd}+0.05 \%$ in $P$. crispus (Figure 3 ). At $96 \mathrm{~h}$, the highest anthocyanin concentrations were determined in $4 \mathrm{mg} \mathrm{L}^{-1}$ $\mathrm{Cd}+5 \% \mathrm{NaCl}(\mathrm{P}<0.05)$ and the lowest in $64 \mathrm{mg} \mathrm{L}^{-1} \mathrm{Cd}+$ $5 \% \mathrm{NaCl}$ in $M$. heterophyllum $(\mathrm{P}<0.05)$ and $P$. crispus $(P>0.05)$ (Figure 3).

\section{Total phenolics}

The total phenolic compounds increased with increasing $\mathrm{Cd}+\mathrm{NaCl}$ concentrations in both treatment periods $(24 \mathrm{~h}$ and $96 \mathrm{~h}$ ). In both M. heterophyllum and P. crispus, the 
Table. 1. The combined effects of $\mathrm{Cd}$ and $\mathrm{NaCl}$ on total phenolic compounds in $M$. heterophyllum and $P$. crispus at 24 and $96 \mathrm{~h}$. Each value indicates the mean \pm standard deviation ( $\mu \mathrm{g} / \mathrm{mg} \mathrm{FW}$ ).

\begin{tabular}{lcccc}
\hline \multirow{2}{*}{ Treatments } & \multicolumn{2}{c}{ Myriophyllum heteropyhllum } & \multicolumn{2}{c}{ Potamogeton crispus } \\
\cline { 2 - 5 } & $\mathbf{2 4} \mathbf{~}$ & $\mathbf{9 6} \mathbf{~}$ & $\mathbf{2 4} \mathbf{~}$ & $\mathbf{9 6} \mathbf{~}$ \\
\hline Control & $55.62 \pm 2.67$ & $57.10 \pm 8.00$ & $67.37 \pm 6.70$ & $69.83 \pm 5.56$ \\
$4(\mathrm{mg} / \mathrm{L}) \mathrm{Cd}+0.05 \% 0 \mathrm{NaCl}$ & $61.00 \pm 0.50$ & $63.80 \pm 4.10$ & $71.68 \pm 6.80$ & $73.09 \pm 4.58$ \\
$4(\mathrm{mg} / \mathrm{L}) \mathrm{Cd}+5 \% 0 \mathrm{NaCl}$ & $62.00 \pm 1.20$ & $64.40 \pm 5.20$ & $72.20 \pm 4.44$ & $73.86 \pm 4.33$ \\
$64(\mathrm{mg} / \mathrm{L}) \mathrm{Cd}+0.05 \% 0 \mathrm{NaCl}$ & $73.30 \pm 0.34$ & $76.18 \pm 0.97$ & $80.50 \pm 4.56$ & $83.68 \pm 6.70$ \\
$64(\mathrm{mg} / \mathrm{L}) \mathrm{Cd}+5 \% 0 \mathrm{NaCl}$ & $74.70 \pm 0.23$ & $77.21 \pm 5.38$ & $82.00 \pm 5.21$ & $86.70 \pm 12.00$ \\
\hline
\end{tabular}

highest level of phenolic compound was found in $64 \mathrm{mg}$ $\mathrm{L}^{-1} \mathrm{Cd}+5 \% 0 \mathrm{NaCl}$ at $24 \mathrm{~h}$ and $96 \mathrm{~h}$ (Table 1) $(\mathrm{P}<0.05)$. Meanwhile, the level of phenolic compounds was higher in $P$. crispus than $M$. heterophyllum (Table 1 ).

\section{DISCUSSION}

In the present study, the contents of chlorophyll a, chlorophyll $b$ and carotenoids decreased due to the time and the increasing concentrations of $\mathrm{Cd}+\mathrm{NaCl}$ in both species (Figures 1 and 2). Photosynthetic activity of plants can decrease under various stress conditions (Santos, 2004; Singh et al., 2005; Mobin and Khan, 2007; Sivaci et al., 2004, 2008). Garg and Singla (2004) reported that the chlorophyll concentrations were decreased by salt stress in chickpea cultivars. Rai et al. (2005) reported that increasing Cd concentration caused a decrease in the concentrations of chlorophyll a, chlorophyll b and carotenoids in Phyllanthus amarus and chlorophyll b was more sensitive than chlorophyll a. In another study, pigment contents in leaves of Alternanthera philoxeroides (chlorophyll a, chlorophyll b and carotenoids) decreased by increasing the $\mathrm{Cd}$ gradient concentrations (Ding et al., 2007). Frittoff et al. (2005) determined that the toxic effect of Cd decreased due to forming complexes of the chloride ions with heavy metals such as $\mathrm{Zn}$ and $\mathrm{Cd}$ under high salinity in Elodea canadensis and $P$. natans. In Zea mays, the chlorophyll content decreased at various levels of salinity or following $\mathrm{Cd}$ treatment. In contrast, there was an increase in chlorophylls in combined $\mathrm{Cd}$ and $\mathrm{NaCl}$ according to the report of Sepehr and Ghorbanli (2006). When compared the results of the present study and Sivacı et al. (2008), it was found that the decrease of chlorophyll a, chlorophyll $\mathrm{b}$ and carotenoids contents in combined effect with $\mathrm{Cd}$ $+\mathrm{NaCl}$ was lesser than the samples treated with $\mathrm{Cd}$ alone in the two macrophytes at $24 \mathrm{~h}$. Hale et al. (2001) reported that molybdenum was accumulated in peripheral cell layer probably forming a complex with anthocyanin in Brassica rapa and the levels of anthocyanin were in concordant with Mo concentration. In another study, an increase in anthocyanin was observed in $B$. juncea cultivars with $\mathrm{Cd}$ stress and these findings indicated that the accumulation of anthocyanin may be only of secondary importance in living cells (Mobin and Khan, 2007). As mentioned in these studies, we determined an increase in the anthocyanin contents of two macrophytes at the some combination of $\mathrm{Cd}$ and $\mathrm{NaCl}$ concentrations by passage of time (Figure 3 ).

The plants can accumulate phenolic compound in their organs due to biotic and abiotic stress (Draper, 1997). Ksouri et al. (2007) investigated the effects of salinity on phenolic compounds in Cakile maritima which grows in different regions. In their study, there was a variation in the accumulation of phenolic compounds in the species due to salinity, as to genetic structure and environment. According to Ferrat et al. (2003), biotic/abiotic stress induces the synthesis of polipherol and accumulation of these compounds in plants. Also, phenolic compounds have intra- and inter-specific competition capacity and the most make a significant contribution to antioxidant activity of plants by bounding the heavy metals. In another study about Myriophyllum spicatum and Myriophyllum triphyllum, Sivaci et al. (2007) found that Cd affected the phenolic compounds at certain concentrations in both species and this effect changed as to species. In our study, the content of phenolic compounds increased depending on combination of $\mathrm{Cd}$ and $\mathrm{NaCl}$ concentrations in the two species and this corresponds with the investigations aforementioned. This result showed that plants may be accumulating the phenolic compounds under various stress conditions.

\section{Conclusion}

The level of pigments (chlorophyll a, chlorophyll b, carotenoids and anthocyanin) and phenolic compounds changed depending on the time (24 and $96 \mathrm{~h}$ ) in stressed aquatic plants. According to the obtained results, chlorophyll $\mathrm{a}$, chlorophyll $\mathrm{b}$ and carotenoids contents of the two aquatic plants decreased at all $\mathrm{Cd}+\mathrm{NaCl}$ concentrations by time ( 24 and $96 \mathrm{~h}$ ), but anthocyanin concentrations increased in some concentrations. Also, total phenolic compounds in these two aquatic plants increased with increasing $\mathrm{Cd}+\mathrm{NaCl}$ concentrations in both treatment periods ( 24 and $96 \mathrm{~h}$ ). 


\section{REFERENCES}

Al-Rub A, El-Naas FA, Ashour MHI, Al-Marzouqi M (2006). Biosorption of copper on Chlorella vulgaris from single, binary and ternary metal aqueous solutions. Process. Biochem., 41: 457-464.

Aravind P, Prassad MNV (2003). Zinc alleviates Cd-induced oxidative stress in Ceratophyllum demersum L.: a free floating freshwater macrophyte. Plant Physiol. Biochem., 41: 391-397.

Chandler SF, Dodds JH (1983). The effect of phosphate, nitrogen and sucrose on the production of phenolics and solasidine in callus cultures of Solanium lacinitum. Plant cell Rep., 2: 105.

De Kok LJ, Graham M (1989). Level of pigments, soluble proteins, amino acids and sulphydryl compounds in foliar tissue of Arabidopsis thaliano during dark-induced and natural senescence. Plant Physiol. Biochem., 27: 203-209.

Ding B, Shi G, Xu Y, Hu J, Xu Q (2007). Physiological responses of Alternanthera philoxeroides (Mart.) Griseb leaves to cadmium stress. Environ. Pollut., 147: 800-803.

Draper J (1997). Salicyclate, superoxide synthesis and cell suicide in plant defense. Trends Plants Sci., 2: 162-165.

Ferrat L, Pergent-Martini C, Romeo M (2003). Assessment of the use of biomarkers in aquatic plants for the evolution of environmental quality: application to seagrasses. Aquat. Toxic., 65: 187-204.

Frittoff A, Kautsky L,Greger M (2005). Influence of temperature and salinity on heavy metal uptake by submersed plants. Environ. Pollut., 133: 265-274.

Garg N, Singla R (2004). Growth, photosynthesis, nodule nitrogen and carbon fixation in the chickpea cultivars under salt stress. Braz. J. Plant Physiol., 6(3): 137-146.

Hale KL, Mcgrath SP, Lombi E, Stack SM, Terry N, Pickering IJ, George GN, Pilon-Smits EAH (2001). Molybdenum sequestration in Brassica species. A role for anthocyanins. Plant Physiol., 126: 1391-1402.

Keskinkan O, Goksu MZL, Yuceer A, Basibuyuk M, Forster CF (2003). Heavy metal adsorption characteristics of a submerged aquatic plant (Myriophyllum spicatum). Process Biochem., 39: 179-183.

Ksouri R, Megdiche W, Debez A, Falleh H, Grignon C, Abdelly C (2007). Salinity effects on polyphenol content and antioxidant activities in leaves of the halophyte Cakile maritime. Plant Physiol. and Biochem., 45: 244-249.

Lichtenthaler HK, Wellburn AR (1983). Determination of total carotenoids and chlorophylls $a$ and $b$ of leaf extracts in different solvents. Biochem. Soc. Trans., 11: 591-592.

Mancinelli AL, Huang-Yang CP, Lindquist $\mathrm{P}$, Anderson OR, Rabino I (1975). Photocontrol of anthocyanin synthesis. III. The action of streptomycin on the synthesis of chlorophyll and anthocyanin. Plant Physiol., 55: 251-257.

Mobin M, Khan NA (2007). Photosynthetic activity, pigment composition and antioxidative response of two mustard (Brassica juncea) cultivars differing in photosynthetic capacity subjected to cadmium stress. J. Plant Physiol., 164: 601-610.

Pasqualini V, Robles C, Garzino S, Greff S, Bousquet-Melou A, Bonin G (2003). Phenolic compounds content in Pinus halepensis Mill. Neddles: a bioindicator of air pollution. Chemosphere, 52: 239-248.
Rai V, Khatoon S, Bisht SS, Mehrotra S (2005). Effect of cadmium on growth, ultramorphology of leaf and secondary metabolites of Phyllanthus amarus Schumm and Thonn. Chemospere, 61: 16441650.

Reay FP, Fletcher RH, Thomas VJG (1998). Chlorophylls, carotenoids and anthocyanin concentrations in the skin of 'Gala' apples during maturation and the influence of foliar applications of nitrogen and magnesium. J. Sci. Food Agric., 76: 63-71.

Santos CV (2004). Regulation of chlorophyll biosynthesis and degradation by salt stress in sunflower leaves. Scientia Hort., 103: 93-99.

Sepehr MF, Ghrorbanli M (2006). Physiological responses of Zea mays seedling to interactions between cadmium and salinity. J. İntegr. Plant Biol., 47: 807-813.

Shin HW, Sidharthan M, Young KS (2002). Forest fire ash impact on micro- and macroalgae in the receiving waters of the east coast of South Korea. Marine Pollut. Bull., 45: 203-209.

Singh S, Eapen S, Souza SFD (2005). Cadmium accumulation and its influence on lipid peroxidation and antioxidative system in an aquatic plant, Bacopa monnieri L. Chemosphere, 62: 233-246.

Sivaci R, Sivaci A, Sökmen M (2004). Biosorption of cadmium by Myriophyllum spicatum L. and Myriophyllum triphyllum Orchard. Chemosphere, 56: 1043-1048.

Sivaci A, Sivaci ER, Sökmen M (2007). Changes in antioxidant activity, total phenolic and abscisic acid constituents in the aquatic plants Myriophyllum spicatum L. and Myriophyllum triphyllum Orchard exposed to cadmium. Ecotoxicol., 16: 423-428.

Sivaci A, Elmas E, Gümüş F, Sivaci ER (2008). Removal of Cadmium by Myriophyllum heterophyllum Michx. and Potamogeton crispus L. and Its Effect on Pigments and Total Phenolic Compounds. Arch. Environ. Contam. Toxi., 54: 612-618.

Slinkard K, Singleton VL (1977). Total phenol analyses: automation and comparison with manual methods. Am. J. Enol. Vitic., 28: 49-55. 